\title{
A study of Intestinal helminthic parasitic infection in Qena governorate inhabitants
}

Mohammed Essa $^{\text {a }}$, Osama Abdellah ${ }^{\text {, }}$ Asmaa M. El-Kady ${ }^{\text {, }}$, Ayat Elsaman ${ }^{\text {b }}$

a Medical Parasitology Department, Faculty of Medicine, Assuit University, Egypt

${ }^{\mathbf{b}}$ Medical Parasitology Department, Faculty of Medicine, South Valley University, Qena, Egypt.

Background: Parasitic diseases continue to be a major cause of morbidity and mortality. More than three billion people are infected worldwide, mainly in the developing countries. Children are easy prey to parasites. Poverty, illiteracy, poor hygiene, lack of access to potable water, poor public health infrastructure, hot and humid tropical climate are the usual factors associated with intestinal parasitic infections. Parasitic infections, particularly intestinal helminthes, cause hundreds of thousands of avoidable deaths each year

Objective: To Assessment of the prevalence of parasitic helminthes infection among Qena governorate residents.

Patients and method(s): Across sectional study was carried out on 316 patients, 5-50 years attended the outpatient clinics of Qena Faculty of Medicine, South Valley University, between August 2017 and August 2018. Stool samples were collected and examined by Direct wet mount and Concentration techniques including sedimentation using saline and formol ethyl acetate.

Result(s):In the studied cases, intestinal helminthic parasitic infections were found in $40(12.5 \%)$ cases out of 316 patients. Positive cases were 30 male patients (75\%), while 10 female patients (25\%), 27 (67.5\%) patient out of 197 aged from 5-19 years, $0(0 \%)$ patients out of 70 from 20-34 years and 13 $(32.5 \%)$ out of 49patientfrom 35-50 years, 10 of patients from urban houses $(25 \%)$ and 30 of patients from rural houses $(75 \%), 19(47.5 \%)$ were present with abdominal pain , $9(22.5 \%)$ with diarrhea and $12(30 \%)$ with perianal itching

Conclusion: Qena governorate suffer from intestinal helminthic parasitic infection mainly in rural areas in children and young adults from 5-19 years old.

Keywords: intestinal helminthes, Qena governorate, prevalence

\section{Introduction}

Parasitic diseases continue to be a major cause of morbidity and mortality. More than three billion people are infected worldwide, mainly in the developing countries. Children are easy prey to parasites. Poverty, illiteracy, poor hygiene, lack of access to potable water, poor public health infrastructure, hot and humid tropical climate are the usual factors associated with intestinal parasitic infections (Evering and Weiss 2006). Approximately 300 million people with heavy helminth infections suffer from severe morbidity that results in more than 150,000 deaths annually (Bethony et al., 2006)

The greatest numbers of soil-transmitted helminths infections occur in tropical and subtropical regions of Asia, especially China,
Saharan Africa. Of the 1-2 billion soiltransmitted helminths infections worldwide, approximately 300 million infections result in severe morbidity, which are associated with the heaviest worm burdens (Hotez et al., 2003)

Infections with intestinal helminths are among the most common intestinal infections of humans. They occur worldwide and are most prevalent in the poorest communities of the developing world (Bundy, 1994)

In Egypt, intestinal parasitic infection in children is a common public health problem; in all governorates it was identified among infants, preschool and school children (Ibrahium, 2011). Though the reported prevalence rates indifferent parts of Egypt vary considerably from one study 
to another ranging from $27 \%$ to $56 \%$ of the children are suffering from intestinal parasites(Mansour at al., 2013).In addition $47.0 \%$ of children are worryingly suffering from intestinal parasites and anemia (UNICEF ,2000).

Age and sex-related behavioral habits, eating habits, socioeconomic status as well as inadequate access to sanitation, to clean water and personal hygiene are the commonest risk factors cited for intestinal parasitic infections (Hotez et al., 2014).Children are at highest risk of infection and carry the highest disease burden (Tchuenté 2011).About 400 million school-age children around the world are infected with roundworm, whipworm and hookworm (Lang, 2005)

An estimated 4.5 billion individuals are at risk of STHs and as many as 1.4 billion individuals might be infected with $A$. Lumbricoides, close to 1.05 billion with $T$. Trichiura, and more than 1.3 billion with hookworms(Keiser; Utzinger, 2008) (WHO, 2002)

The greatest numbers of soil-transmitted helminths infections occur in tropical and subtropical regions of Asia, especially China, India and Southeast Asia, as well as sub-Saharan Africa(Hotez et al., 2003)

In Egypt, intestinal parasitic infection in children is a common public health problem; in all governorates it was identified among infants, preschool and school children (Ibrahium, 2011). Though the reported prevalence rates indifferent parts of Egypt vary considerably from one study to another ranging from $27 \%$ to $56 \%$ of the children are suffering from intestinal parasites(Mansour at al., 2013).In addition $47.0 \%$ of children are worryingly suffering from intestinal parasites and anemia (UNICEF, 2000) The aim of this study is to Assessment of the prevalence of parasitic helminthes infection among Qena governorate residents.

\section{Subjects and Methods:}

Across sectional studywas carried out on 316 patients, 5-50 years attended the outpatient clinics of Qena Faculty of Medicine, South
Valley University, between August 2017 and August 2018.

In the present study, after obtaining an informed written consent, 316 stool samples were collected from patients attending outpatient clinics in Qena university Hospital South Valley University

Patients subjected to the study show symptoms suggestive of parasitic infections such as abdominal colic, diarrhea, constipation, anal itching, organomegaly or jaundice.

Patients was asked to bring 3 consecutive stool samples to be examined for possible parasitic helminthes finding.Specimens were examined within one hour of collection after detailed history from children: age, sex, residence, complaint (diarrhea, abdominal pain, anorexia, nausea, vomiting and anal itching) by the following methods:

\section{Direct smear method:}

Mixing a small amount of stool (about $2 \mathrm{mg}$ ) with a drop of $0.85 \% \mathrm{NaCl}$ (Garcia 2007):these are used for identification of eggs or larvae for Helminths

\section{Concentration technique:}

Simple sedimentation with $0.85 \% \mathrm{Nacl}$ and Formol- Ether Sedimentation technique: (Garcia 2007)to increase the efficacy of centrifugal sedimentation for recovery and concentration of helminths eggs from faeces.

\section{Statistical analysis}

Data were organized, tabulated, and statistically analyzed using SPSS version, 20.0. For quantitative data, mean and standard deviation were calculated. Chi-square test $\left(\chi^{2}\right)$ was used to compare the frequency data.

\section{Results:}

In the present study Intestinal helminthic parasitic infections were found in $40(12.5 \%)$ cases out of 316 patients as illustrated in Table (1) and Figure (1) 
Table (1): illustrate prevalence of negative and positive cases in the study group of patients.

\begin{tabular}{|l|l|l|}
\hline & Frequency & Percent \\
\hline Negative cases & 276 & 87.5 \\
Positive cases & 40 & 12.5 \\
Total & 316 & 100.0 \\
\hline \multicolumn{2}{|c|}{ prevalence } \\
$12.5 \%$ \\
\multicolumn{2}{|c|}{} \\
\hline
\end{tabular}

Figure (1) illustrate prevalence of negative and positive cases in the study group of patients

Positive cases were 30 male patients $(75 \%)$, while 10 female patients (25\%), $27(67.5 \%)$ patient out of 197 aged from 5-19 years, $0(0 \%)$ patients out of 70 from 20-34 years and 13 $(32.5 \%)$ out of 49patientfrom 35-50 years, 10ofpatients from urban houses $(25 \%)$ and 30 of patients from rural houses (75\%),19 (47.5\%) were present with abdominal pain , $9(22.5 \%)$ with diarrhea and $12(30 \%)$ with perianal itching as illustrated in Table (2)

Table 2: Show socio-demographic risk factors and different clinical presentation of parasitic infection.

\begin{tabular}{|l|l|l|}
\hline Characteristics & $\begin{array}{l}\text { Positive cases } \\
(40)\end{array}$ & $\begin{array}{l}\text { Percentage } \\
(\%)\end{array}$ \\
\hline Age & & $67.5 \%$ \\
$20-34$ & 27 & $0 \%$ \\
$35-50$ & 0 & $32.5 \%$ \\
\hline Gender & 13 & $75 \%$ \\
Male & 30 & $25 \%$ \\
Female & 10 & $75 \%$ \\
\hline Residence & 30 & \\
Rural & & \\
\hline
\end{tabular}

\begin{tabular}{|l|l|l|}
\hline Urban & 10 & $25 \%$ \\
\hline Abdominal pain & & \\
Yes & 19 & $47.5 \%$ \\
No & 21 & $52.5 \%$ \\
\hline Diarrhea & 9 & $22.5 \%$ \\
Yes & 31 & $77.5 \%$ \\
No & 12 & $30 \%$ \\
\hline Perianal itching & & $70 \%$ \\
Yes & 28 & \\
No & & \\
\hline
\end{tabular}

In the present study 30 male patients were infected with intestinal helminthic infections with percentage $75 \%$, while 10 female patients were infected with intestinal helminthic infections with percentage $25 \%$. Thus, gender was considered to be a risk factor for acquiring intestinal helminthic infections. $(\mathrm{P}$ value $=0.02$ which is a significant value). According to Table (3) and Figure (2)

Table (3): Relationship between gender and prevalence of intestinal helminthic infections in cases

\begin{tabular}{|c|c|c|c|c|c|}
\hline \multirow[b]{2}{*}{ Gender } & & \multicolumn{2}{|c|}{ group } & \multirow[b]{2}{*}{ Total } & \multirow{2}{*}{$\begin{array}{l}\mathrm{P} \\
\text { value }\end{array}$} \\
\hline & & $\begin{array}{l}\mathrm{Neg} \\
\text { ativ } \\
\mathrm{e} \\
\text { case } \\
\mathrm{s}\end{array}$ & $\begin{array}{l}\text { Positiv } \\
\text { e cases }\end{array}$ & & \\
\hline $\begin{array}{l}\text { Femal } \\
\text { e }\end{array}$ & $\begin{array}{l}\text { Count } \\
\% \text { within } \\
\text { group }\end{array}$ & $\begin{array}{l}117 \\
42.4 \\
\%\end{array}$ & $\begin{array}{l}10 \\
25 \%\end{array}$ & $\begin{array}{l}127 \\
40.2 \%\end{array}$ & \multirow[t]{3}{*}{0.02} \\
\hline Male & $\begin{array}{l}\text { Count } \\
\% \text { within } \\
\text { group }\end{array}$ & $\begin{array}{l}159 \\
57.6 \\
\%\end{array}$ & $\begin{array}{l}30 \\
75 \%\end{array}$ & $\begin{array}{l}189 \\
59.8 \%\end{array}$ & \\
\hline Total & $\begin{array}{l}\text { Count } \\
\% \text { within } \\
\text { group }\end{array}$ & $\begin{array}{l}276 \\
100 . \\
0 \%\end{array}$ & $\begin{array}{l}40 \\
100.0 \\
\%\end{array}$ & $\begin{array}{l}316 \\
100.0 \%\end{array}$ & \\
\hline
\end{tabular}




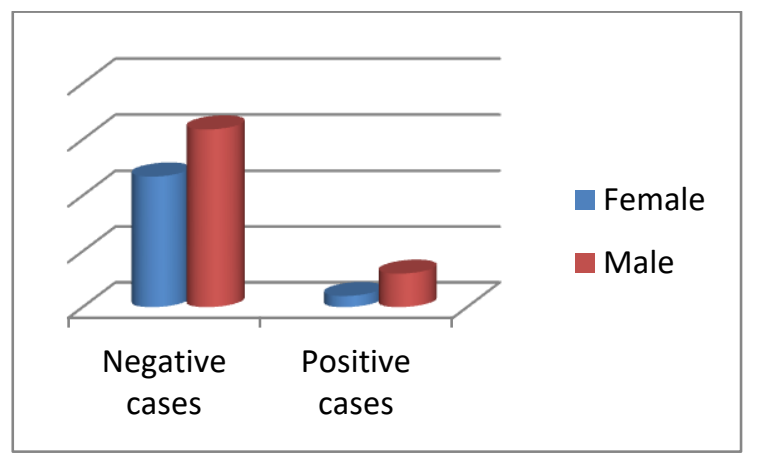

Figure (2): Relationship between gender and prevalence of intestinal helminthic infections in cases

the intestinal helminthic parasitic infection in positive cases were in $27(67.5 \%)$ patient out of 197 aged from 5-19 years, $0(0 \%)$ patients out of 70 from 20-34 years and $13(32.5 \%)$ out of 49patientfrom 35-50 years $(\mathrm{p}$ value $=0.001)$. According to Table(4) and Fig.(3),

Table(4):Distribution of positive and negative cases according to their age

\begin{tabular}{|c|c|c|c|c|c|c|c|}
\hline $\begin{array}{l}\text { Age } \\
\text { grou } \\
p\end{array}$ & \multicolumn{2}{|c|}{$\begin{array}{l}\text { Number of } \\
\text { tested } \\
\text { patients \& } \\
\%\end{array}$} & \multicolumn{2}{|c|}{$\begin{array}{l}\text { Number } \\
\text { of } \\
\text { Positive } \\
\text { cases \& } \\
\%\end{array}$} & \multicolumn{2}{|c|}{$\begin{array}{l}\text { Number of } \\
\text { Negative } \\
\text { cases \& } \\
\%\end{array}$} & $\begin{array}{l}\mathrm{P} \\
\text { valu } \\
\mathrm{e}\end{array}$ \\
\hline $5-19$ & $\begin{array}{l}19 \\
7\end{array}$ & $\begin{array}{l}62.3 \\
\%\end{array}$ & $\begin{array}{l}2 \\
7\end{array}$ & $\begin{array}{l}67.5 \\
\%\end{array}$ & $\begin{array}{l}17 \\
0\end{array}$ & $\begin{array}{l}61.5 \\
\%\end{array}$ & $\begin{array}{l}0.00 \\
0\end{array}$ \\
\hline $\begin{array}{l}20- \\
34\end{array}$ & 70 & $\begin{array}{l}22.1 \\
\%\end{array}$ & 0 & $0 \%$ & 70 & $\begin{array}{l}25.4 \\
\%\end{array}$ & \\
\hline $\begin{array}{l}35- \\
50\end{array}$ & 49 & $\begin{array}{l}15.5 \\
\%\end{array}$ & $\begin{array}{l}1 \\
3\end{array}$ & $\begin{array}{l}32.5 \\
\%\end{array}$ & 36 & $\begin{array}{l}13.1 \\
\%\end{array}$ & \\
\hline Tota & $\begin{array}{l}31 \\
6\end{array}$ & $100 \%$ & $\begin{array}{l}4 \\
0\end{array}$ & $\begin{array}{l}100 \\
\%\end{array}$ & $\begin{array}{l}27 \\
6\end{array}$ & $\begin{array}{l}100 \\
\%\end{array}$ & \\
\hline
\end{tabular}

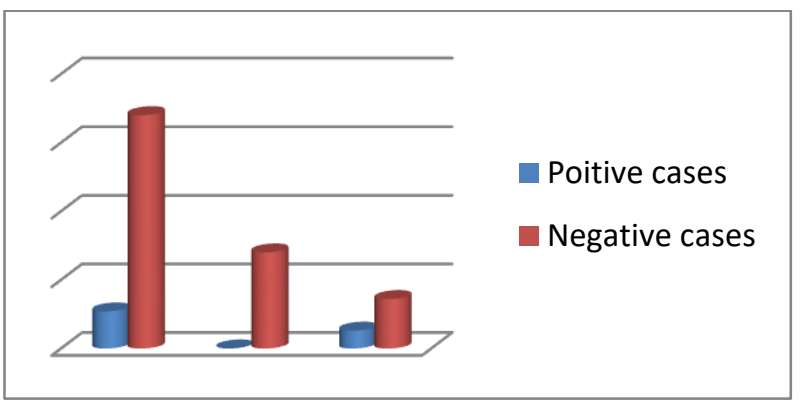

Figure (3):Distribution of positive and negative cases according to their age

intestinal helminthic parasitic infection were detected in 10ofpatients from urban houses $(25 \%)$ and 30 of patients from rural houses $(75 \%) . p$ value $=0.002$ According to table (5) and figure (4)

Table(5): Relationship between residence and prevalence of intestinal helminthic infections in cases

\begin{tabular}{|c|c|c|c|c|c|}
\hline \multirow{2}{*}{\multicolumn{2}{|c|}{ Residence }} & \multicolumn{2}{|l|}{ group } & \multirow[b]{2}{*}{ Total } & \multirow{2}{*}{$\begin{array}{l}\mathrm{P} \\
\text { valu } \\
\mathrm{e}\end{array}$} \\
\hline & & $\begin{array}{l}\text { Negativ } \\
\text { e cases }\end{array}$ & $\begin{array}{l}\text { Positiv } \\
\text { e cases }\end{array}$ & & \\
\hline Rural & $\begin{array}{l}\text { Coun } \\
\mathrm{t} \\
\% \\
\text { withi } \\
\mathrm{n} \\
\text { group }\end{array}$ & $\begin{array}{l}137 \\
49.6 \%\end{array}$ & $\begin{array}{l}30 \\
75 \%\end{array}$ & $\begin{array}{l}167 \\
52.8 \%\end{array}$ & .002 \\
\hline $\begin{array}{l}\text { Urba } \\
n\end{array}$ & $\begin{array}{l}\text { Coun } \\
\mathrm{t} \\
\% \\
\text { withi } \\
\mathrm{n} \\
\text { group }\end{array}$ & $\begin{array}{l}139 \\
50.4 \%\end{array}$ & $\begin{array}{l}10 \\
25 \%\end{array}$ & $\begin{array}{l}149 \\
47.2 \%\end{array}$ & \\
\hline Total & $\begin{array}{l}\text { Coun } \\
\mathrm{t} \\
\% \\
\text { withi } \\
\mathrm{n} \\
\text { group }\end{array}$ & $\begin{array}{l}276 \\
100.0 \%\end{array}$ & $\begin{array}{l}40 \\
100.0 \\
\%\end{array}$ & $\begin{array}{l}316 \\
100.0 \\
\%\end{array}$ & \\
\hline
\end{tabular}




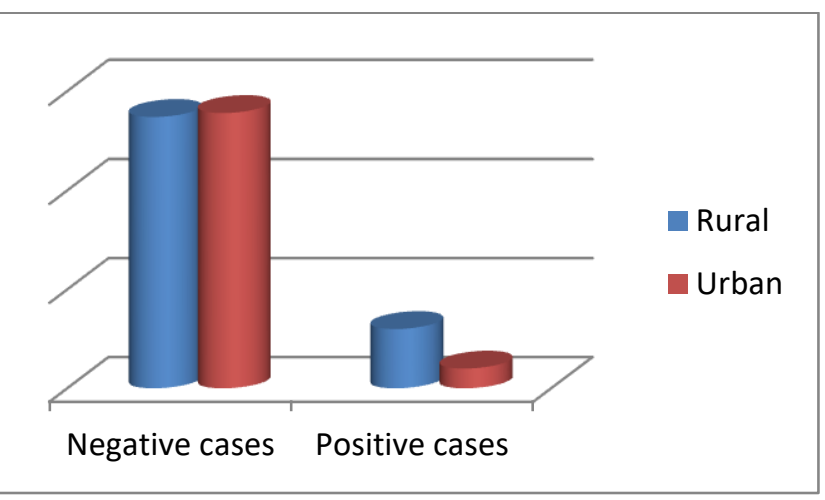

Figure (4):Relationship between residence and prevalence of intestinal helminthic infections in cases

In the present study $19(47.5 \%)$ patients of the cases were present with abdominal pain, $9(22.5 \%)$ were present with diarrhea and 12 $(30 \%)$ were present with perianal itching. P value 0.001 According to table (6) and figure (5)

Table (6): Distribution of intestinal helminthic parasitic infection in patients according to Clinical picture.

\begin{tabular}{|c|c|c|c|c|c|}
\hline \multirow{2}{*}{\multicolumn{2}{|c|}{ Clinical picture }} & \multicolumn{2}{|l|}{ group } & \multirow[t]{2}{*}{ Total } & \multirow{2}{*}{$\begin{array}{l}\mathrm{P} \\
\text { value }\end{array}$} \\
\hline & & $\begin{array}{l}\text { Negative } \\
\text { cases }\end{array}$ & $\begin{array}{l}\text { Positive } \\
\text { cases }\end{array}$ & & \\
\hline $\begin{array}{l}\text { Abdominal } \\
\text { pain }\end{array}$ & $\begin{array}{l}\text { Count } \\
\% \\
\text { within } \\
\text { group }\end{array}$ & $\begin{array}{l}208 \\
75.4 \%\end{array}$ & $\begin{array}{l}19 \\
47.5 \%\end{array}$ & $\begin{array}{l}228 \\
72.2 \%\end{array}$ & .000 \\
\hline Diarrhea & $\begin{array}{l}\text { Count } \\
\% \\
\text { within } \\
\text { group }\end{array}$ & $\begin{array}{l}68 \\
24.6 \%\end{array}$ & $\begin{array}{l}9 \\
22.5 \%\end{array}$ & $\begin{array}{l}77 \\
24.4 \%\end{array}$ & \\
\hline $\begin{array}{l}\text { Perianal } \\
\text { itching }\end{array}$ & $\begin{array}{l}\text { Count } \\
\% \\
\text { within } \\
\text { group }\end{array}$ & $\begin{array}{l}0 \\
0.0 \%\end{array}$ & $\begin{array}{l}12 \\
30 \%\end{array}$ & $\begin{array}{l}11 \\
3.5 \%\end{array}$ & \\
\hline Total & $\begin{array}{l}\text { Count } \\
\% \\
\text { within } \\
\text { group }\end{array}$ & $\begin{array}{l}276 \\
100.0 \%\end{array}$ & $\begin{array}{l}40 \\
100.0 \%\end{array}$ & $\begin{array}{l}316 \\
100.0 \%\end{array}$ & \\
\hline
\end{tabular}

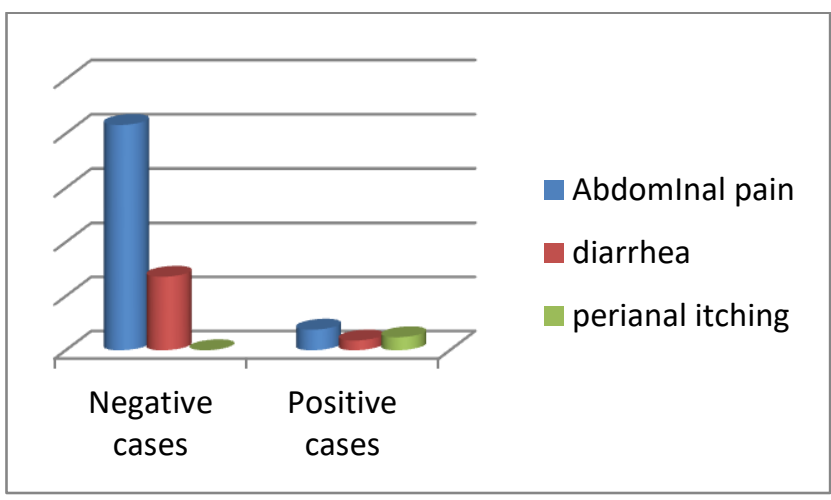

Figure (5): Distribution of intestinal helminthic parasitic infection in patients according to Clinical picture.

Examination of the collected stool samples of the studied population, the results show $12.5 \%$ of overall had intestinal helminthic parasitic infection. The commonest detected parasite were asfollowing:Hymenolepis nana egg (4.7 $\%)$, Enterobiusvermicularis egg (2.5 \%), Enterobiusvermicularis egg and adult $(0.9 \%)$, Taeniasaginata egg (2.8 \%) andAncylostomaduodenale egg (0.9\%).As illustrated in Table (7) and Figure (6)

Table (7): showed the prevalence of different intestinal helminthic parasites in the study group

\begin{tabular}{|l|l|l|}
\hline Parasite & Frequency & Percentage \\
\hline $\begin{array}{l}\text { 1-Ancylostoma } \\
\text { duodenale eggs } \\
\text { 2-Enterobius } \\
\text { vermicularis egg } \\
\text { 3-Enterobius } \\
\text { vermicularis egg and }\end{array}$ & 3 & $0.9 \%$ \\
adult & 4 & $2.8 \%$ \\
$\begin{array}{l}\text { 4-Hymenolepis nana } \\
\text { egg saginata }\end{array}$ & 9 & $15 \%$ \\
$\begin{array}{l}\text { 5-Taenia eggs } \\
\text { eggs }\end{array}$ & & \\
6-Negative cases & 276 & $8.7 \%$ \\
Total & 316 & $100.0 \%$ \\
\hline
\end{tabular}




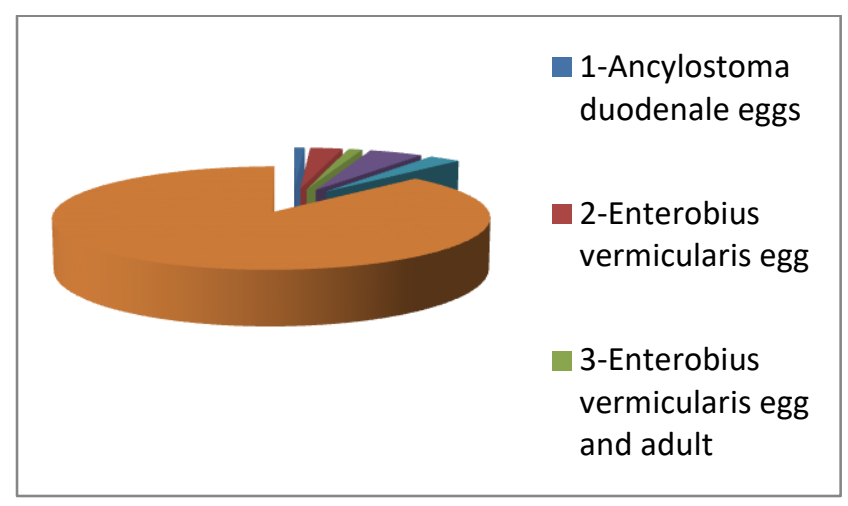

Figure (6): showed the prevalence of different intestinal helminthic parasitesin the study group

\section{Discussion:}

Parasitic diseases continue to be a major cause of morbidity and mortality. More than three billion people are infected worldwide, mainly in the developing countries. Children are easy prey to parasites. Poverty, illiteracy, poor hygiene, lack of access to potable water, poor public health infrastructure, hot and humid tropical climate are the usual factors associated with intestinal parasitic infections (Evering and Weiss 2006).

Parasitic infections, particularly intestinal helminthes, cause hundreds of thousands of avoidable deaths each year. Intestinal helminthes are more prevalent throughout the tropics, especially among poor communities. Records show increasing trends in helminthiasis infections, particularly in developing nations (Bdiret al., 2010).

The present study was done on 316 patients from Qena Governorate Hospitals from outpatients, Intestinal helminthic parasitic infections were found in $40(12.5 \%)$ cases out of 316 patients.

The prevalence was nearly similar to the study by (Hussein et al., 2017) who found Out of 100 patients, among patients with gastrointestinal tract disorders from the Greater Cairo region the prevalence of parasitic infection was $11.7 \%$
And The study by (Abd El Mageed et al., 2010) conducted in 1920 School Aged Children attending Pediatric Department of AlAzhar and Assiut University Hospitals, their ages ranged from 6 to 16 years .The percentage of parasitic infections was $16.5 \%$.

Also in the study done by Samehet al., 2013,the study included 1000 young adult men, attending for medical advice for different gastrointestinal symptoms in Qena University Hospital the results of stool analysis of the studied population, $9.5 \%$ had intestinal helminthic parasitic infection.the prevalence is nearly similar as both studies were conducted at same region, Qena governorate

In another study, Henin, (2008) studied the prevalence of parasitic infections among children in Abu El-Reesh Hospital in Cairo and reported that the rate was $64 \%$ out of 860 children

Also Abdel-Rahman, (2003) recorded a rate of $66.3 \%$ among school children in a village in west of Alexandria out of 569 cases.

In the study by Farghly et al., 2016, the prevalence of parasitic infections among school children in Zagazig district was $(21.07 \%)$ out of 859 children. The prevalence in this study was relatively high due to bad hygienic measures, reduced health education, warm climate, humid atmosphere, consumption of large quantities of raw vegetables without washing, direct contamination of food and drink by infective flies, lack of central sewage disposable system and home septic tanks, poor water supply and deficiency of primary health care centers

In the study by (Osama AbdElla et al., 2015) done on 798 patients their age from 2 -65 years old attended to Qena University Hospital, 359 $(44.98 \%)$ were positive for gastrointestinal helminthic infection. These differences may be because the wide variation in the sample sizes between their study (798 cases) and ours (316 cases)

In comparison to a study done In Ethiopia conducted between March 29 and April 9, 2010 to determine the prevalence and intensity of soil transmitted helminths among elementary school 
children, Of the total 715 stool specimens examined, 326 were positive for at least one intestinal parasite making the prevalence $45.6 \%$ (Tefera et al., 2017)

Also Panda et al., 2012 reported that (55.6\%) of school children were found to be positive for intestinal parasites in Vizianagaram district in India, while Kassem et al., 2007 reported a rate of $56 \%$ among children in Libya.

\section{Conclusion:}

Qena governorate suffer from intestinal helminthic parasitic infection mainly in rural areas in children and young adults from 5-19 years old

\section{References:}

Abd El Mageed MB, Hamed, AM, Nafisa, HR, Abdelaziz, AHA, Monazea, EM, AbdElkreem HE, Mohamed, S. A. (2010). Prevalence and risk factors associated with worm infestation in school aged children in AlAzhar and Assiut university hospitals. AAMJ, 8(3):88-106.

Abdel-Rahman M. (2003).Ecological factors affecting the prevalence of some parasitic infections among elementary school children in a village in west of Alexandria.M.Sc. Thesis, Parasitology Dep., Alexandria University.

Bdir S, Adwan G. (2010). Prevalence of intestinal parasitic infections in Jenin Governorate, Palestine: a 10-year retrospective study. Asian Pacific Journal of Tropical Medicine, 3(9): 745-747.

\section{Bethony J, Brooker S, Albonico M, Geiger SM,} Loukas A, Diemert D, Hotez PJ. (2006). Soiltransmitted helminth infections: ascariasis, trichuriasis, and hookworm. The lancet, 367(9521): 1521-1532.

Bundy DAP. (1994). The global burden of intestinal nematode disease. Transactions of the Royal Society of Tropical Medicine and Hygiene, 88(3): 259-261.

Evering T, Weiss LM (2006): The immunology of parasite infections in immunocompromised hosts. Review Article. Parasite Immunol, 28:549-565.

Farghly AM, Mohamed SM, Abdel-Rahman, SA, Mohammed FE, El-Bahaie ES, El-Shafey, MA. (2016). The relation between the prevalence of soil transmitted parasites in the soil and among school children in Zagazig district, Sharkyia Governorate, Egypt. Journal of Parasitic Diseases, 40(3): 1021-1029.

Garcia LS. (2007). Diagnostic Medical Parasitology, ed. 5, ISBN 1-55581-380-1: 86.

Henin RW. (2008).Intestinal helminthes in children with asthma.M.Sc. Thesis, Parasitology Dep. Cairo University.

Hotez, PJ, Alvarado M, Basáñez MG, Bolliger I, Bourne R, Boussinesq M, CarabinH. (2014). The global burden of disease study 2010: interpretation and implications for the neglected tropical diseases. PLoS neglected tropical diseases, 8(7): e2865.

Hotez PJ, da Silva N, Brooker S, Bethony J. (2003). Soil transmitted helminth infections: The nature, causes and burden of the condition (Working Paper No. 3, Disease Control Priority Project). Bethesda, MD: Fogarty International Center, National Institutes of Health.

Hussein AH, Rashed SM, El-Hayawan IA, Aly N S, Ouf EAA, Ali AT. (2017).Intestinal parasite infections and accuracy of direct thin and thick smear, formol-ether sedimentation, centrifugal flotation, and mini-FLOTAC techniques among patients with gastrointestinal tract disorders from the Greater Cairo region, Egypt. The American journal of tropical medicine and hygiene, 96(3): 589-594.

Ibrahium FA. (2011). Prevalence and predisposing factors regarding intestinal parasitic infections among rural primary school pupils at Minia Governorate, Egypt. Journal of public health in Africa, 2(2).

Kassem HH,Zaed HA, Sadga GA. (2007).intestinal parasitic infection among children and neonates admitted to Ibn-Sina 
Hospital, Sirt, Libia. Journal of Egyptian Society of Parasitology, 37(2): 371-380.

Keiser J, Utzinger J. (2008). Efficacy of current drugs against soil-transmitted helminth infections: systematic review and metaanalysis. Jama, 299(16): 1937-1948.

Lang T. (2005). North Nigeria. Nigerian J.Parasitol, 26: 19-22.

Mansour AM,Mohammady HE, Shabrawi ME, Shabaan SY, Zekri AM. (2013). Modifiable diarrhea risk factors in Egyptian children aged 1-5 years.Epidemiol.Infect; 141: 2547-59.

Osama, HA, Shamardan, AEM, Zaytoun, SS, Nermean M. (2015).Ascarislumbricoides and other Gastrointestinal Helminthic Parasites among Qena Inhabitants with special concern to its Relation to Anemia and Eosinophilia. IOSR, 14(12): 98-105.

Panda S, Rao UD, Sankaram KR. (2012).Prevalence of intestinal parasitic infections among school children in rural area of Vizianagaram. IOSR J Pharm BiolSci, 3(3):42-4.

Sameh Z, AbdElla OH, Ghweil A A, Hussien SM, Ayoub HA, Taha AMA.(2013). Prevalence of intestinal parasitosisamong male youth in QenaGovernorate (Upper Egypt), and its relation to socio-demographic characteristics and some morbidities. Life Science Journal, 10(3).

Tchuenté LT. (2011). Control of soiltransmitted helminths in sub-Saharan Africa: diagnosis, drug efficacy concerns and challenges. Actatropica, 120: S4-S11.

Tefera E, Belay T, Mekonnen SK, Zeynudin A, Belachew T. (2017). Prevalence and intensity of soil transmitted helminths among school children of Mendera Elementary School, Jimma, Southwest Ethiopia. The Pan African medical journal, 27.

UNICEF (2000).Egypt demographic and health survey report. UNICEF Egypt.

WHO (2002). The prevention and control of schistosomiasis and soil transmitted helminthiasis. Geneva: World Health Organization; Technical Report Series No.9 
